\title{
Salicylic Acid Can Induce Resistance to Plant Virus Movement
}

\author{
Martin Naylor, Alex M. Murphy, James O. Berry, and John P. Carr \\ Department of Plant Sciences, University of Cambridge, Downing Street, Cambridge CB2 3EA U.K. \\ Accepted 9 June 1998.
}

\begin{abstract}
Salicylic acid (SA) treatment has recently been reported to inhibit replication of tobacco mosaic virus (TMV) in inoculated tissue. Furthermore, resistance is induced via a novel defensive signal transduction pathway sensitive to inhibition by salicylhydroxamic acid (SHAM; S. Chivasa, A. M. Murphy, M. Naylor, and J. P. Carr, Plant Cell 9: $547-557,1997)$. The goals of this study were to determine if replication of viruses other than TMV could be inhibited by $\mathrm{SA}$ and, if so, whether the resistance to other viruses could also be prevented by SHAM. Potato virus X (PVX) RNA accumulation in inoculated tobacco leaf tissue was reduced by $S A$ treatment and resistance was dependent on the SHAM-sensitive signaling pathway. However, although symptoms of cucumber mosaic virus (CMV) infection were delayed in SA-treated tobacco plants, this was not due to inhibition of replication but rather to inhibition of systemic movement of the virus. ${ }^{14} \mathrm{CO}_{2}$-feeding experiments indicated that $\mathrm{SA}$-induced interference with longdistance virus movement is not a by-product of disrupted photosynthate translocation. Significantly, SA-induced resistance to CMV was abolished by SHAM. Thus, the SHAM-sensitive signaling pathway activates both resistance mechanisms: inhibition of long-distance CMV movement and inhibition of TMV and PVX replication.
\end{abstract}

Additional keywords: alternative oxidase, systemic acquired resistance.

Salicylic acid (SA) is an important component in the signal transduction pathway leading to systemic acquired resistance (SAR) to the entire spectrum of plant pathogens: bacteria, fungi, and viruses (reviewed by Ryals et al. 1996 and Durner et al. 1997). The most common trigger for SA synthesis and the induction of SAR is the hypersensitive response (HR: localized cell death at the point of pathogen entry), which results from the interaction of a host resistance gene product with a specific pathogen-produced elicitor (Staskawicz et al. 1995). One of the best-studied model systems for investigations of HR and the induction of SAR is the interaction between tobacco mosaic virus (TMV) and tobacco plants possessing the $N$ gene. The $N$ gene encodes a receptor protein able to recognize specific sequences in the $126-\mathrm{kDa} \mathrm{TMV}$

Corresponding author: John P. Carr

E-mail: jpc1005@hermes.cam.ac.uk

Permanent address of J. O. Berry: Department of Biological Sciences, State University of New York at Buffalo, Buffalo 14260, U.S.A. replicase protein (Whitham et al. 1994; Padgett et al. 1997). This recognition event leads to the HR, in which the virus is restricted to the tissue immediately surrounding necrotic lesions that form at the viral inoculation sites. The HR is followed by an increase in SA levels in the plant (Malamy et al. 1990; Métraux et al. 1990) leading to SAR, which is manifested by the production of fewer, smaller necrotic lesions in response to a second challenge with TMV (Ross 1961a, 1961b). SA is also required to prevent spread of the virus beyond the immediate vicinity of the HR lesions (Mur et al. 1997). However, exogenous application of SA or the synthetic resistance-inducing chemical benzo(1,2,3)thiadiazole-7-carbothioic acid methyl ester (BTH) can also induce some degree of resistance to viruses even in plants that do not possess a corresponding resistance gene and that, therefore, would in normal circumstances be completely susceptible (White et al. 1983; Hooft van Huijsduijnen et al. 1986; Friedrich et al. 1996).

SA induces a range of defense genes, most notably those encoding the pathogenesis-related (PR) proteins, several of which have been shown to possess antifungal or antibacterial properties (Bowles 1990). It is less clear how SA mediates resistance to viruses but it was shown recently that treatment with SA caused the accumulation of TMV RNA to be reduced in directly inoculated, TMV-susceptible tobacco leaf tissue (Chivasa et al. 1997). It was also found that the ratio of genomic RNA to coat protein (CP) mRNA and the ratio of plus- to minus-sense RNAs were affected by SA treatment (Chivasa et al. 1997). These findings suggested that SA induces interference with the activity of the TMV RNA-directed RNA polymerase (RdRp). At the whole plant level this resistance to the virus was manifested as a delay in the onset of systemic TMV disease. Furthermore, it was also shown that salicylhydroxamic acid (SHAM), an inhibitor of the plant mitochondrial alternative oxidase (AOX; for reviews see Laties 1982; Raskin 1992; McIntosh 1994; Day et al. 1995), antagonized the SA-induced delay in TMV disease in TMVsusceptible tobacco, as well as SA-induced acquired resistance in tobacco plants possessing the $N$ gene (Chivasa et al. 1997). However, SHAM treatment did not prevent the induction of the PR-1 PR protein or resistance to a fungal and a bacterial pathogen (Chivasa et al. 1997).

These results suggested that the defensive signal transduction pathway separates downstream of SA into two branches. It was proposed that one branch leads to induction of resistance to TMV and is SHAM sensitive (and potentially requires AOX activity to function), while the other pathway (SHAM insensitive) leads to the induction of antifungal and 
antibacterial mechanisms (Chivasa et al. 1997). This model is consistent with the emerging view of antimicrobial signal transduction as a web of converging and branching signaling pathways (Baker et al. 1997; Reuber and Ausubel 1996; Ritter and Dangl 1996; Xu et al. 1994), including some branches that may be SA independent (Durner et al. 1997; Vidal et al. 1998).

The initial aims of this work were to determine (i) if the replication of viruses other than TMV was inhibited in directly inoculated tissues in SA-treated tobacco plants, and (ii) whether resistance was induced via the SHAM-sensitive signaling pathway. The viruses used in this study were potato virus $\mathrm{X}$ (PVX) and cucumber mosaic virus (CMV). Like TMV, these viruses are positive-sense RNA viruses with broad host ranges that include important crop species. PVX is similar to TMV in that it is a monopartite virus, whereas CMV has a tripartite RNA genome (Brunt et al. 1997; Palukaitis et al. 1992). Our results indicate that SA can induce resistance to viruses by two different mechanisms. SA can either induce interference with replication in the directly inoculated tissue, as seen previously for TMV (Chivasa et al. 1997), or it can induce an inhibition of long-distance movement. However, both of these resistance mechanisms were found to require the operation of the SHAM-sensitive branch of the defensive signal transduction pathway.

\section{RESULTS}

\section{The effects of SA on replication of PVX, CMV, and TMV in inoculated tissue.}

The effects of SA on PVX replication in directly inoculated tissue were examined by Northern (RNA) blot analysis of viral RNA accumulation in leaf disk tissue previously treated with SA. It was found that SA inhibited PVX RNA accumulation in SA-treated tissue (Fig. 1). However, in overexposed Northern blots (data not shown) it was seen that although viral RNA accumulation was greatly reduced it was not completely

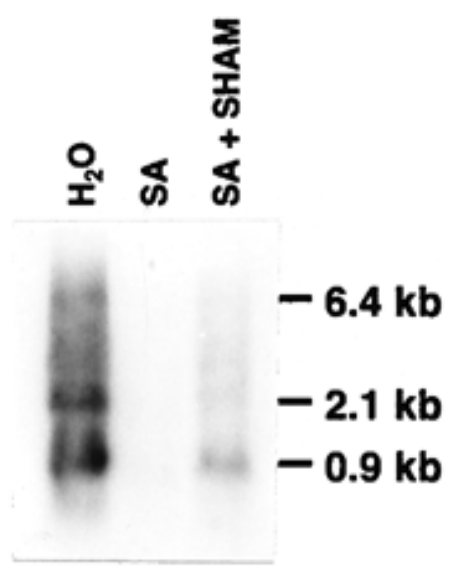

Fig. 1. Effect of salicylic acid (SA) treatment on accumulation of potato virus X (PVX) RNAs in inoculated tobacco tissue. Equal quantities of single-stranded RNA extracted from pooled tobacco leaf disks (10 disks [10 $\mathrm{mm}$ in diameter] per solution) were analyzed by Northern (RNA) blotting with a ${ }^{32} \mathrm{P}$-labeled PVX-specific riboprobe (Köhm et al. 1993). Leaf disks were floated for 5 days on water $\left(\mathrm{H}_{2} \mathrm{O}\right), 1 \mathrm{mM} \mathrm{SA}(\mathrm{SA})$, or a solution containing $1 \mathrm{mM}$ each of $\mathrm{SA}$ and salicylhydroxamic acid (SHAM) (SA + SHAM). After this pretreatment, disks were inoculated with PVX $(10 \mu \mathrm{g} / \mathrm{ml})$ and incubated for an additional 2 days prior to RNA extraction. PVX-specific RNA bands are indicated by size in kb. suppressed, and that the accumulation of the three PVXspecific RNAs was reduced to different extents. The AOX inhibitor SHAM antagonized SA-induced resistance to PVX from occurring although the presence of SHAM did not completely restore PVX RNA accumulation to normal (Fig. 1). Densitometric quantitation of Northern blot data from three experiments indicated that the SA treatment typically caused a decrease in PVX RNA accumulation of greater than 10-fold (Table 1). However, the presence of SHAM in the incubation mix resulted, typically, in only an approximately 50\% decrease in PVX RNA accumulation (Table 1). Similar quantitative and qualitative effects have been observed previously for TMV RNA accumulation in SA-treated tobacco tissue, leading to the suggestion that SA treatment of plant tissue can induce interference with viral RdRp activity through the action of a SHAM-sensitive signal transduction pathway (Chivasa et al. 1997). Thus, it appears likely that SA also stimulates resistance to PVX via a similar mechanism and that resistance to PVX and TMV are induced by the same signal transduction pathway.

However, in stark contrast to the results obtained with TMV (Chivasa et al. 1997) and PVX (Fig. 1), it was found that treatment with SA, or with the biologically inactive isomer of SA, 3hydroxybenzoic acid, did not reduce CMV replication in inoculated tobacco leaf disks (Fig. 2). Furthermore, SA had no obvious effect on the amounts of CMV-specific RdRp activity that could be extracted from leaves directly inoculated with CMV, whereas SA treatment greatly decreased the amount of TMVspecific RdRp that could be extracted from TMV-inoculated leaves (Fig. 3). Thus, it appears that SA cannot induce a significant degree of resistance to CMV in inoculated tissue.

The results of the experiments with crude TMV RdRp extracts from SA-treated tissue raised the possibility that SA might function directly as an inhibitor of TMV RdRp activity. Therefore, in some experiments SA (1 mM final concentration) was added to in vitro incubations of crude TMV RdRp preparations extracted from TMV-inoculated leaf tissue that had not been previously treated with SA. It was found that this had no effect on the pattern of TMV-specific, radiolabeled RNA produced (data not shown). Thus, it remains most likely that SA acts as an inducer of resistance to TMV replication rather than as a direct inhibitor of TMV RdRp enzyme activity.

SA induces resistance to CMV at the whole plant level.

Since the above observations indicated that it is unlikely that SA has a major effect on the replication of CMV it ap-

Table 1. Densitometric analysis of potato virus X (PVX) RNA accumulation in tobacco leaf tissue

\begin{tabular}{lc}
\hline Treatment $^{\mathbf{a}}$ & Densitometer reading $^{\mathbf{b}}$ \\
\hline Control & $142 \pm 4.7$ \\
SA & $9.6 \pm 16.7$ \\
SA plus SHAM & $74 \pm 26$ \\
\hline
\end{tabular}

${ }^{a}$ Tobacco leaf disks were floated on water (Control), or solutions of salicylic acid (SA) or SA plus salicylhydroxamic acid (SHAM) before inoculation with PVX (see caption to Figure 1 for experimental details).

b Total RNA was extracted from leaf disks and subjected to Northern (RNA) analysis with a PVX-specific probe (see Figure 1 caption for experimental details). Intensity of the PVX 0.9-kb RNA in each gel lane was measured densitometrically. Values shown are means $( \pm$ standard deviaton) of Northern analysis of RNA samples from three independent experiments (one of which was used for Figure 1) analyzed side by side on the same Northern blot (not shown). 
peared reasonable to predict that SA would have no effect on the systemic disease symptoms caused by CMV. Surprisingly, this proved not to be the case. Tobacco plants watered with 1 $\mathrm{mM}$ SA for 3 days prior to CMV inoculation consistently showed a delay of 5 to 6 days in the onset of systemic symptoms, compared with untreated plants (Table 2), and in each experiment some plants never showed evidence of systemic infection (data not shown). Thus, despite having no apparent effect on the replication of CMV in inoculated tissues, SA was

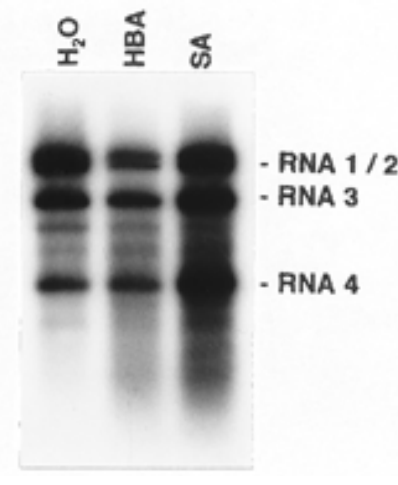

Fig. 2. Accumulation of cucumber mosaic virus (CMV) RNAs in directly inoculated, salicylic acid (SA)-treated tissue. Equal quantities of single-stranded RNA extracted from pooled tobacco leaf disks (5 disks [10 $\mathrm{mm}$ in diameter] per solution) were analyzed by Northern (RNA) blotting with a ${ }^{32} \mathrm{P}$-labeled riboprobe complementary to the $3^{\prime}$-terminal sequences common to the genomic CMV RNAs 1, 2, and 3 as well the subgenomic RNA 4 (Gal-On et al. 1994). Leaf disks were floated for 5 days on water $\left(\mathrm{H}_{2} \mathrm{O}\right), 1 \mathrm{mM}$ 3-hydroxybenzoic acid (HBA), or $1 \mathrm{mM} \mathrm{SA}$ (SA) before inoculation with CMV $(10 \mu \mathrm{g} / \mathrm{ml})$. Disks were incubated for an additional 2 days prior to RNA extraction.
A

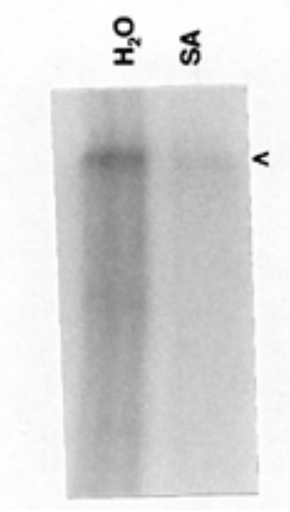

B

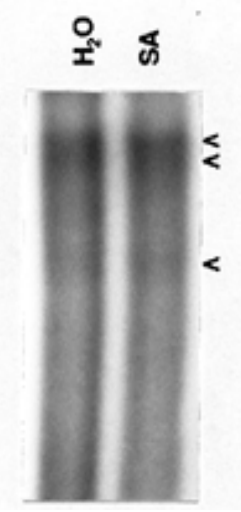

Fig. 3. The effect of salicylic acid (SA) on viral RNA-directed RNA polymerase (RdRp) activity. Partially purified RdRp extracts were obtained from (A) tobacco mosaic virus (TMV)-inoculated and (B) cucumber mosaic virus (CMV)-inoculated leaves from both untreated $\left(\mathrm{H}_{2} \mathrm{O}\right)$ and SA-treated (SA) tobacco plants. RdRp preparations were incubated in the presence of $\alpha\left[{ }^{32} \mathrm{P}\right]$-UTP to permit RNA synthesis to recommence in vitro with endogenous RNA as template. Nascent, radiolabeled RNAs were analyzed by polyacrylamide gel electrophoresis and autoradiography. Similar levels of CMV-specific RdRp activity were present in extracts from untreated and SA-treated, CMV-inoculated tissue, (B) but levels of TMV-specific RdRp activity were lower in extracts from SA-treated plants than in extracts from unteated plants (A). B, Arrowheads indicate (in descending order) positions of double-stranded forms of RNAs 1 and 2 (which migrate too closely together to resolve separately), RNA 3, and subgenomic RNA 4. able to delay development of the systemic disease symptoms caused by this virus.

\section{SA treatment delays the exit of CMV from inoculated leaves.}

Was the SA-induced delay in the onset of the disease caused by CMV due merely to an inhibition of symptom development, or was it an expression of genuine resistance to the virus? In order to answer this question we examined the effects of SA on the distribution of CMV in the tissues of SAtreated and untreated control plants by Western blot (immunoblot) analysis of CMV coat protein (CP). CMV CP accumulation was examined in soluble protein extracts from directly inoculated leaves, stem tissue, and upper uninoculated leaves (Fig. 4). It was found that CMV CP accumulated in the in-

Table 2. The effect of salicylic acid (SA) on systemic symptoms in cucumber mosaic virus (CMV)-inoculated tobacco plants ${ }^{\mathrm{a}}$

\begin{tabular}{lccccc}
\hline & \multicolumn{5}{c}{ Time point when plants showed symptoms ${ }^{\mathbf{b}}$} \\
\cline { 2 - 6 } Treatment $^{\mathbf{c}}$ & $\mathbf{1 0} \mathbf{d p i}$ & $\mathbf{1 5} \mathbf{d p i}$ & $\mathbf{4} \mathbf{d p i}$ & $\mathbf{6 ~ d p i}$ & $\mathbf{1 1} \mathbf{d p i}$ \\
\hline Experiment 1 & & & & & \\
SA & $0 / 3$ & $2 / 3$ & & & \\
Control & $3 / 3$ & $3 / 3$ & & & \\
Experiment 2 & & & & & \\
SA & & & $0 / 3$ & $0 / 3$ & $2 / 3$ \\
Control & & & $1 / 4$ & $4 / 4$ & $4 / 4$ \\
\hline
\end{tabular}

${ }^{\mathrm{a}}$ Both experiments were carried out under greenhouse conditions. Experiment 1 was carried out during winter and experiment 2 during early summer; hence the more rapid onset of disease in experiment 2.

${ }^{b}$ Vein clearing and/or early mosaic symptoms in upper leaves. The first time point shown for each experiment was when symptoms were first obtained on any control plants; the last time point was when symptoms were first observed on any SA-treated plants. $\mathrm{dpi}=$ days post inoculation.

${ }^{\mathrm{c}}$ Four- to 5-week-old tobacco (Xanthi NN) in groups of three were either watered normally (Control) or with $1 \mathrm{mM} \mathrm{SA}$ for 3 days prior to inoculation on one lower leaf with cucumber mosaic virus (CMV; 5 $\mu \mathrm{g} / \mathrm{ml})$.

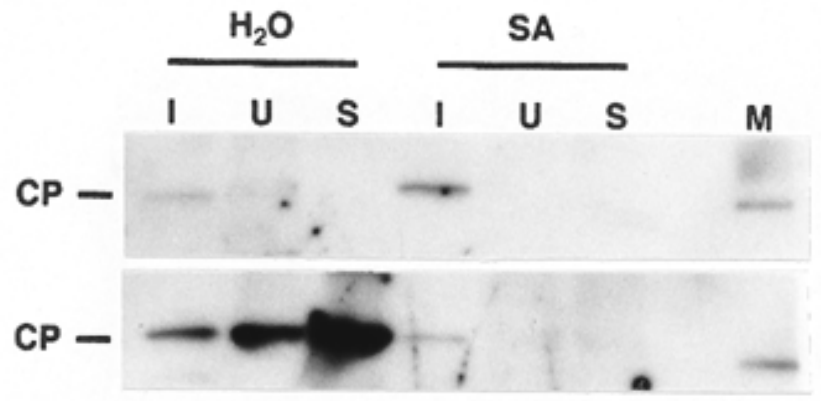

Fig. 4. Distribution of cucumber mosaic virus (CMV) coat protein (CP) in salicylic acid (SA)-treated plants. Total soluble protein extracts were prepared from leaves inoculated directly with $5 \mu \mathrm{g}$ of $\mathrm{CMV}$ per $\mathrm{ml}(\mathrm{I})$, from the stem (S) adjacent to the inoculated leaf, and from the upper, uninoculated leaves $(\mathrm{U})$ of tobacco plants that had been previously watered with $1 \mathrm{mM} \mathrm{SA}$ for 3 days (SA), or left untreated $\left(\mathrm{H}_{2} \mathrm{O}\right)$. Extracts were prepared from plants at 3 and 8 days post inoculation (dpi) (upper and lower panels, respectively) and analyzed by Western blotting (immunoblotting) with a polyclonal antiserum raised against CMV CP. Binding of the antibody was detected with $\left[{ }^{125} \mathrm{I}\right]$-protein $\mathrm{A}$ and autoradiography. Lane M: authentic CMV CP used as a marker. A lane was left empty between the protein extracts and the marker lane. CP, position of authentic CMV CP band. 
oculated leaves of both SA-treated and untreated leaves at all time points examined (Fig. 4), consistent with the data on accumulation of CMV-specific RNAs in inoculated tissue (Fig. 2). However, there was a significant delay in the appearance of CMV CP in stem tissue and upper uninoculated leaves of SA-treated plants (Fig. 4). By 8 days post inoculation (dpi) CMV CP was present in all tissues of untreated, CMVinoculated plants, whereas it was not yet apparent in stems and upper leaves of SA-treated plants (Fig. 4). However, by $10 \mathrm{dpi}$ CMV CP accumulation and viral RNA were detectable in the stem and upper leaves of the SA-treated plants (data not shown), although symptoms were not apparent until a few days later. Thus, the delay in the onset of systemic CMV disease symptoms observed in SA-treated plants (Table 2) appears to be result of a delay in virus movement out of the inoculated leaf.

\section{TMV-induced HR can stimulate resistance to CMV.}

Experiments were performed to determine if the inhibition of CMV movement observed in plants treated with exogenous SA would also occur in plants expressing SAR (Malamy et al. 1990). Pathogen-induced expression of SAR was achieved by inoculating NN genotype tobacco plants on one side of a lower leaf with $10 \mu \mathrm{g}$ of TMV per ml. Control plants were mockinoculated on one half-leaf. Three days later, by which time necrotic lesions had appeared on the TMV-inoculated half-leaves, the opposite half-leaves were inoculated with CMV $(5 \mu \mathrm{g} / \mathrm{ml})$. By 10 dpi with CMV, systemic CMV disease symptoms were clearly visible on the upper leaves of the plants that had originally been mock-inoculated (Fig. 5A), but not on the upper leaves of plants originally inoculated with TMV (Fig. 5B). Thus, pathogen-induced SAR impeded the systemic movement of CMV, confirming that our earlier experiments with applied SA had indeed genuinely mimicked the natural phenomenon of SAR and were not artefacts resulting from the exogenous application of unnaturally high concentrations of SA.

\section{SA-induced resistance to CMV is inhibited by SHAM.}

SA-induced resistance to the replication of both TMV (Chivasa et al. 1997) and PVX (Fig. 1) was prevented by SHAM. Thus, it appears that the interference with viral replication in general is probably induced via the SHAM-sensitive signal transduction pathway. Interestingly, the SA-induced resistance to the systemic movement of CMV was also found to be SHAM sensitive. Figure 6B shows the appearance of the upper, uninoculated leaves of tobacco plants 8 days after inoculation with CMV $(5 \mu \mathrm{g} / \mathrm{ml})$ on a lower leaf following watering of the plant with $1 \mathrm{mM}$ SA plus $1 \mathrm{mM}$ SHAM for 3 days prior to inoculation with the virus. In contrast, CMV disease symptoms were absent on plants treated with SA alone (Fig. 6A). Furthermore, Northern blot analysis showed that SHAM prevented the SA-induced delay in CMV RNA accumulation in the upper, uninoculated leaves (Fig. 7). These results indicate that the SHAM-sensitive branch of the defensive signal transduction pathway plays a role not only in the induction of mechanisms that interfere with viral replication, but also in the induction of mechanisms that interfere with viral movement.

\section{Translocation and partitioning of photosynthates in SA-treated tobacco plants.}

How is long-distance movement of CMV disrupted by SA treatment? The movement of many viruses through the phloem parallels the translocation of sugars from mature photosynthetic tissues (net sources of fixed carbon) to less physiologically mature or rapidly growing tissues (net sinks for fixed carbon) (Leisner and Howell 1993; Leisner and Turgeon 1993; Séron and Haenni 1996). In ${ }^{14} \mathrm{CO}_{2}$-feeding experiments a sharp demarcation, called the sink-to-source transition, between the mature and immature zones of developing leaves can be observed by autoradiography (Turgeon 1989). Conceivably, SA might induce a disruption of the normal flow of fixed carbon from source to sink tissues in SA-treated plants that would in turn affect virus long-distance movement. Hypothetically, this might be caused by increased carbohydrate utilization due to the increased levels of AOX known to be induced by SA (Chivasa et al. 1997). Photosynthate partitioning in SA-treated and untreated tobacco plants was compared by feeding the plants with ${ }^{14} \mathrm{CO}_{2}$ and tracking the flow of the newly synthesized, radiolabeled carbon compounds through the plants by autoradiography. However, in four separate experiments comparing one SA-treated and one untreated plant, SA treatment did not produce any obvious disruption to the pattern of ${ }^{14} \mathrm{C}$ labeling or to the position of the carbon sinkto-source transition. A typical set of results is shown in Figure 8.

\section{DISCUSSION}

Our results show that SA can inhibit the development of virus disease in plants in two ways: either by inhibiting replication of the virus at the initial point of infection, or by delaying the movement of the virus out of the inoculated tissue. Thus, the accumulation of TMV and PVX is inhibited in the inoculated tissue, most likely by interference with RdRp activity, while for CMV, which evades the first mechanism, movement out of the inoculated leaf is impeded. Remarkably, both of these distinctly different, SA-induced resistance phenomena were inhibited by SHAM. A SHAM-sensitive branch of the defensive signal transduction pathway has previously been shown to be responsible for induction of acquired resistance to TMV (Chivasa et al. 1997). Thus, it would appear that the SHAM-sensitive signaling pathway participates in induction of resistance to viruses other than TMV and that it can mediate both the induction of interference with virus replication and the inhibition of virus movement.

The results obtained with crude TMV RdRp preparations seen in this study (Fig. 3) are consistent with previous work indicating that SA can induce an inhibition of TMV replication (Chivasa et al. 1997). SA also induced a reduction in the overall levels of PVX-specific RNAs accumulating in directly inoculated tissue and a change in the ratio of PVX full-length to subgenomic RNA levels (Fig. 1 and data not shown). This suggested that resistance to PVX occurs via a mechanism similar to that of SA-induced resistance to TMV, most likely by inducing interference with $\mathrm{RdRp}$ activity. However, the experiments with crude RdRp preparations could be explained in part by effects on local movement, so at this stage an effect on cell-to-cell virus movement cannot be completely ruled out. In contrast, SA did not appear to have any inhibitory effect on CMV-specific RdRp activity, nor did it inhibit accumulation of CMV RNA in directly inoculated tissue. Nonetheless, it did induce delays in both the onset of symptoms and in the appearance of CMV RNA and protein in uninoculated parts of the plant. Taken together these results strongly indi- 

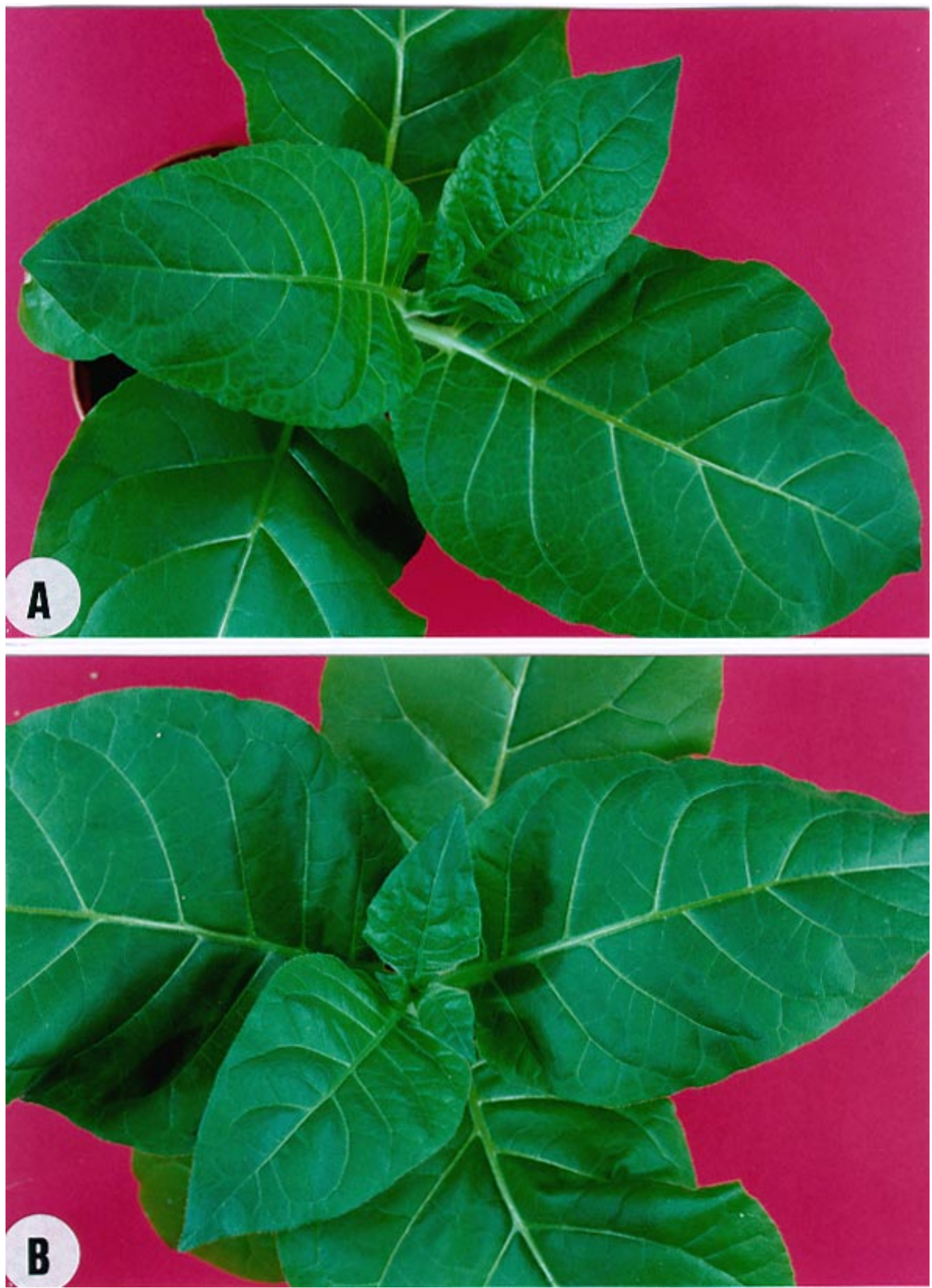

Fig. 5. Cucumber mosaic virus (CMV) disease symptoms in upper leaves of tobacco plants expressing systemic acquired resistance (SAR). Six-week-old Xanthi NN tobacco plants were (A) mock-inoculated or (B) inoculated with $10 \mu \mathrm{g}$ of tobacco mosaic virus (TMV) per ml on a lower leaf (not visible in photographs). After 3 days (by which time hypersenstive lesions had developed on the TMV-inoculated leaf of plant B), both plants were inoculated on the previously mock- or TMV-inoculated leaves a second time with CMV $(5 \mu \mathrm{g} / \mathrm{ml})$. Upper leaves were photographed 10 days after inoculation with CMV. 
cate that SA induces interference with some aspect of longdistance movement of this virus through the vasculature.

In many ways less is known about the processes underlying systemic virus movement than about the movement of viruses between adjacent cells via the plasmodesmata, which is mediated by virus-coded movement proteins (MPs; Carrington et al. 1996; Gilbertson and Lucas 1996). Systemic movement of most viruses occurs in the phloem and follows a pattern simi-
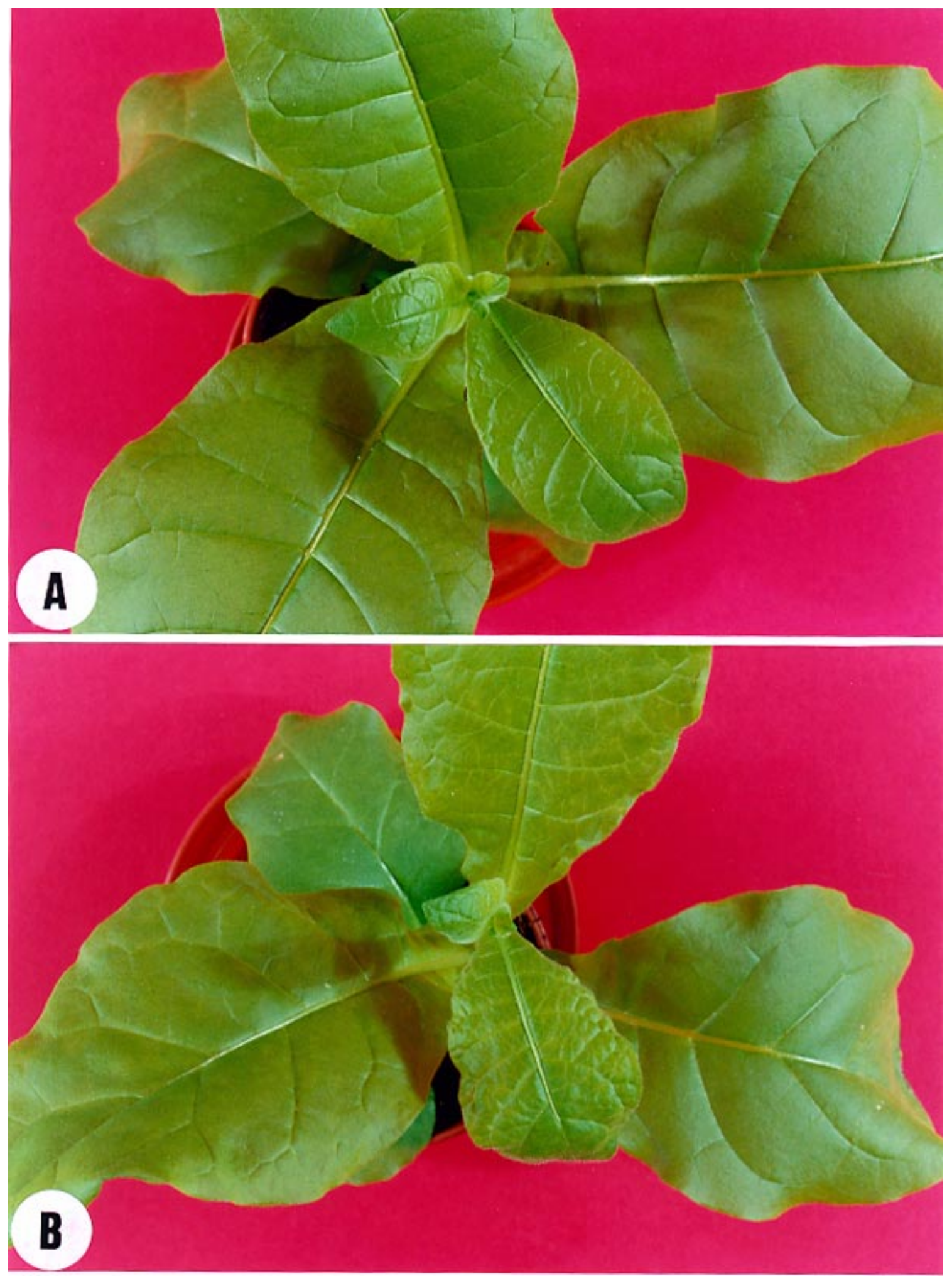

Fig. 6. Effect of salicylhydroxamic acid (SHAM) on symptoms in salicylic acid (SA)-treated cucumber mosaic virus (CMV)-inoculated plants. Disease symptoms on upper, uninoculated leaves of Xanthi nn tobacco plants 8 days after inoculation with CMV on a lower leaf following pretreatment with (A) SA or (B) SA plus SHAM. 
lar to that of photosynthate translocation (Maule 1991; Leisner and Howell 1993; Leisner and Turgeon 1993; Séron and Haenni 1996). Although it should be noted that systemic movement is most influenced by viral gene products other than MPs, for example CPs (Séron and Haenni 1996), expression of genes encoding MPs (for example see Lucas et al. 1993) can disrupt carbohydrate translocation in transgenic plants. This effect might help, at least in part, to explain the complex local changes in carbohydrate metabolism and partitioning seen around sites of virus infection (Técsi et al. 1994). However, although it is clear that movement of viruses and

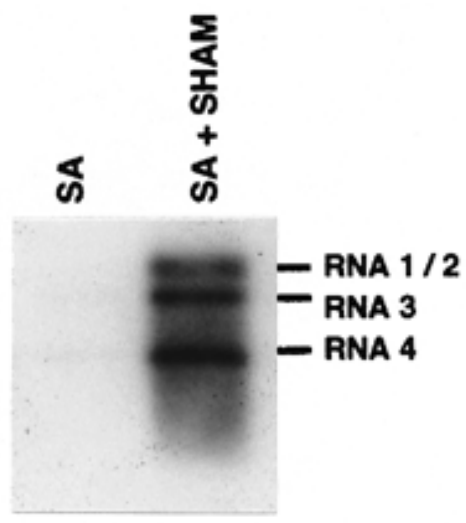

Fig. 7. Effect of salicylhydroxamic acid (SHAM) on cucumber mosaic virus (CMV) RNA accumulation in upper leaves. RNA was extracted from upper, uninoculated leaves of tobacco plants watered with $1 \mathrm{mM}$ salicylic acid (SA) or a mixture of $1 \mathrm{mM}$ SA plus $1 \mathrm{mM}$ SHAM (SA + SHAM) for 3 days prior to inoculation with CMV $(5 \mu \mathrm{g} / \mathrm{ml})$. RNA extractions were performed at 8 days post inoculation from the same upper leaves illustrated here. Equal amounts of RNA were analyzed by Northern (RNA) blotting as described in the Figure 1 caption. movement and metabolism of sugars are intimately bound together, it is not at all clear how these processes are linked mechanistically. Nonetheless, it was tempting to speculate that SA may interfere with long-distance virus movement in an indirect fashion by changing the pattern of photosynthate translocation, for example by inducing changes in respiration by induction of AOX gene expression and activity. However, it was evident from the results of our ${ }^{14} \mathrm{CO}_{2}$-feeding experiments that SA has no gross effect on the translocation of newly fixed carbon or on the boundaries between carbon sink and carbon source tissues (Fig. 8). Thus, SA appears to be inducing a highly specific inhibition of virus movement through the vasculature without causing gross changes in the physiology of carbohydrate transport.

The boundary between the bundle sheath cells and the phloem probably represents an important "checkpoint" controlling virus movement out of inoculated tissue and into the vasculature (Ding et al. 1996; Wintermantel et al. 1997; Thompson and García-Arenal 1998). The results of our studies of CMV distribution in the tissues of CMV-infected plants (Fig. 4) are consistent with an effect on loading of virus across this boundary. Recently, Roberts et al. (1997) used PVX tagged with the jellyfish green fluorescent protein and specific fluorescent dyes to compare in detail how viruses and solutes enter and exit from the vasculature. They found that the finest veins (classes IV and V) do not apparently function in virus unloading in sink tissues but as tissues mature these minor veins may be the sites of virus loading into the vasculature (Roberts et al. 1997). Thus, future studies on the ultrastructure of the minor veins and the distribution of virus between mesophyll, bundle sheath, and phloem cells in SA-treated versus untreated plants may be the way to shed more light on the effects of SA on long-distance virus movement.
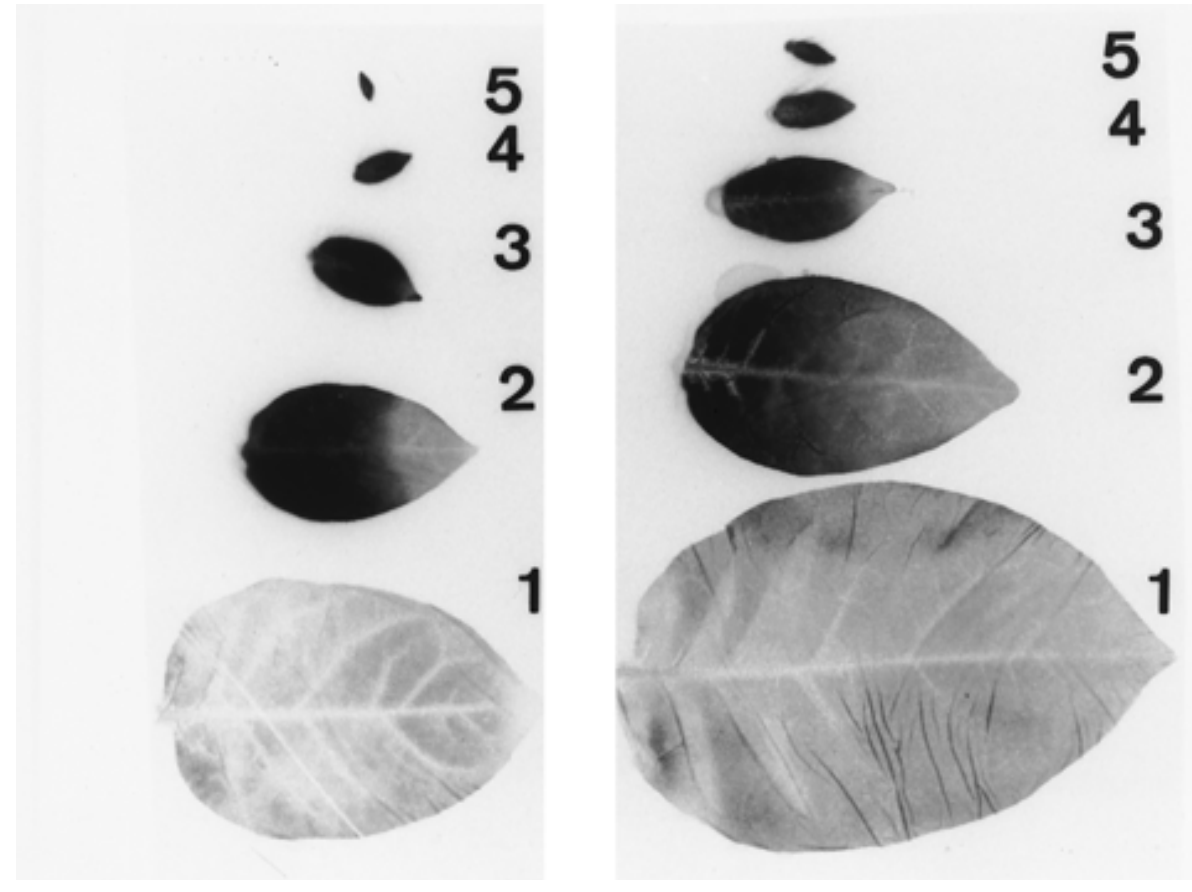

Fig. 8. Localization of ${ }^{14} \mathrm{C}$-labeled photoassimilates in salicylic acid (SA)-treated plants. Autoradiographs of leaves from tobacco plants untreated (left panel) or watered for 3 days with $1 \mathrm{mM}$ SA before exposure to ${ }^{14} \mathrm{CO}_{2}$ (right panel). Numbers next to leaves refer to position of leaf with respect to directly labeled leaves on each plant, with leaf number 1 the lowest and 5 the highest leaf sampled. Directly labeled leaves were not autoradiographed. 
In conclusion, it appears that SA can induce interference with the accumulation of virus at the point of inoculation and also induce inhibition of virus movement out of the inoculated tissue. Both of these SA-induced effects slow down the progress of the disease and the expression of symptoms. Significantly, both of these resistance mechanisms are induced via the novel SHAM-sensitive defensive signal transduction mechanism (Chivasa et al. 1997). Of course, among viruses there may well be varying degrees of sensitivity to the effects of SA. For example, potato virus Y infection is apparently not affected by application of SA to the host plant (Pennazio et al. 1985). However, for the viruses that are affected by SA, it appears that although some may be able to evade SA-induced resistance to replication, they will not be able to overcome the SA-induced barrier to movement out of the inoculated tissue.

\section{MATERIALS AND METHODS}

\section{Plant material and virus strains.}

Tobacco plants (Nicotiana tabacum L. 'Xanthi-nn' and 'Xanthi-NN') for whole plant experiments, leaf disk preparation, and RdRp isolation were maintained under greenhouse conditions with supplementary lighting in winter. Methods for inoculations with virus and treatments of whole plants and excised leaf disks with solutions of SA and/or SHAM have been described (Chivasa et al. 1997). In addition to TMV U1, other viruses used in these experiments were CMV strain Fny and PVX strain UK3 (gifts of P. Palukaitis and S. Santa-Cruz, respectively). Leaf disk incubations were carried out in a Fitotron growth chamber (Sanyo, Leicester, UK) at $25^{\circ} \mathrm{C}$ (for experiments with $\mathrm{CMV}$ ) or $18^{\circ} \mathrm{C}$ (for experiments with $\mathrm{PVX}$ ), with a 16-h photoperiod.

\section{Preparation of crude TMV- and CMV-specific RdRp extracts and analysis of RdRp activity.}

Crude TMV- and CMV-specific RdRp preparations were isolated by a procedure adapted from methods previously described (Hayes and Buck 1990, 1993) for the preparation of CMV RdRp. Xanthi-nn tobacco plants, untreated or watered 4 days previously with $2 \mathrm{mM} \mathrm{SA}$, were inoculated with TMV or CMV $(0.1 \mu \mathrm{g} / \mathrm{ml})$. Inoculated leaves (5 to $10 \mathrm{~g}$ ) were harvested at 3 or 6 dpi and homogenized in two volumes of extraction buffer $\left(50 \mathrm{mM}\right.$ Tris-HCl pH 7.4, $15 \mathrm{mM} \mathrm{MgCl}_{2}, 120$ $\mathrm{mM} \mathrm{KCl}, 20 \% \mathrm{vol} / \mathrm{vol}$ glycerol, $0.1 \mathrm{mM}$ phenylmethylsulfonylfluoride and $0.1 \% \mathrm{vol} / \mathrm{vol} 2$-mercaptoethanol). The homogenate was centrifuged at $4^{\circ} \mathrm{C}$ for $15 \mathrm{~min}$ at $2,000 \times g$. The supernatant was filtered through muslin and centrifuged at $4^{\circ} \mathrm{C}$ for $30 \mathrm{~min}$ at $14,000 \times \mathrm{g}$. Pellets were resuspended in resuspension buffer (50 mM Tris- $\mathrm{HCl} \mathrm{pH} 8.2,10 \mathrm{mM} \mathrm{MgCl}_{2}$, $5 \%$ glycerol, $1 \mathrm{mM}$ dithiothreitol [DTT]). Typically, resuspended extracts had protein concentrations of approximately 4 $\mathrm{mg} / \mathrm{ml}$ as determined by the method of Bradford (1976). Crude RdRp extracts were stored at $-80^{\circ} \mathrm{C}$. $\mathrm{RdRp}$ assays were carried out by incubating a sample of crude RdRp preparation (equivalent to $100 \mu \mathrm{g}$ of protein) with 2 volumes of assay buffer $(100 \mathrm{mM}$ Tris- $\mathrm{HCl} \mathrm{pH}$ 8.2, 8\% vol/vol glycerol, $20 \mathrm{mM}$ $\mathrm{MgCl}_{2}, 2 \mathrm{mM}$ ATP, $2 \mathrm{mM}$ GTP, 2 mM CTP, $50 \mu \mathrm{M}$ UTP, 20 $\mathrm{mM}$ DTT, $0.5 \mu \mathrm{l}$ [20 to $40 \mathrm{U}$ ] RNAsin [Promega, Madison, WI], and $\alpha-\left[{ }^{32} \mathrm{P}\right]$ UTP [10 to $20 \mu \mathrm{Ci}$; Amersham, Little Chalfont, Buckinghamshire, UK]). Reaction mixtures were incubated for 1 to $2 \mathrm{~h}$ at $30^{\circ} \mathrm{C}$ and analyzed by polyacrylamide gel electrophoresis (PAGE) and autoradiography as previously described (Carr et al. 1994).

\section{RNA and protein analyses.}

Extraction of RNA from leaf tissue was carried out by the method of Berry et al. (1985). CMV RNA was detected on Northern blots with a ${ }^{32} \mathrm{P}$-labeled riboprobe complementary to the plus-sense 3' terminal 200 nucleotides common to CMV RNAs 1, 2, 3, and 4 (Gal-On et al. 1994). PVX RNAs were detected on RNA blots with a ${ }^{32} \mathrm{P}$-labeled riboprobe complementary to the $3^{\prime}$ termini shared by the full-length and subgenomic PVX RNAs. This probe was generated by in vitro transcription of ApaI-cut pTXS with T3 RNA polymerase (Köhm et al. 1993). In vitro transcriptions were carried out with a Stratagene kit (Stratagene, La Jolla, CA). Northern blots were imaged by autoradiography with Kodak Biomax film. Autoradiographic signals were quantitated with a densitometer equipped with ImageQuant version 3.0 software (Molecular Dynamics, Cheshunt, UK).

CMV CP was detected in plant tissues by Western blot analysis of total soluble protein extracts (Chivasa et al. 1997) with a polyclonal rabbit antiserum raised against the $\mathrm{CP}$ of CMV strain M (prepared by the late R. I. B. Francki; gift of P. Palukaitis). Antibody binding to the nitrocellulose membrane was detected with $\left[{ }^{125} \mathrm{I}\right]$-protein A (Amersham) and imaged by autoradiography (Berry et al. 1985).

\section{Visualization of photoassimilate transport.}

The pattern of photoassimilate transport was characterized by a modified version of previously described methods (Turgeon and Webb 1973; Leisner et al. 1992; Wang et al. 1993). The three lower leaves of Xanthi NN tobacco plants (5 to 6 weeks old; untreated or watered with $1 \mathrm{mM}$ SA for 4 days) were carefully rolled up and inserted into 50-ml "Falcon" tubes. The gap between the petiole and tube rim was sealed with "Blu-Tac" (Bostik, Leicester UK). ${ }^{14} \mathrm{CO}_{2}$ was generated inside the barrel of a 1-ml syringe by mixing excess $80 \%$ lactic acid with $\mathrm{Ba}^{14} \mathrm{CO}_{3}$ (Amersham). The reaction mixture was injected through the Blu-Tac into the sealed tube. After 45 min of exposure to ${ }^{14} \mathrm{CO}_{2}$ under strong illumination the tubes were removed from the leaves and a further $2 \mathrm{~h}$ allowed for translocation to occur. The accumulation pattern of ${ }^{14} \mathrm{C}$-photosynthates was visualized by autoradiography. The upper leaves of the plant were harvested, wrapped in Saran wrap, and autoradiographed on X-ray film.

\section{ACKNOWLEDGMENTS}

We thank Peter Palukaitis and Simon Santa-Cruz (Scottish Crop Research Institute, Dundee) for gifts of virus and antisera and Steve Chivasa for useful discussions. This work was supported by grants from the Biotechnology and Biological Sciences Research Council (BBSRC grant P03659) and the Leverhulme Trust. M. N. was supported by a studentship from the BBSRC, A. M. M. was supported by postdoctoral fellowships from the BBSRC and the Broodbank fund of Cambridge University, and J. O. B. was supported by visiting fellowships from Gonville and Caius College, Cambridge, and from the Underwood fund of the BBSRC.

\section{LITERATURE CITED}

Baker, B., Zambryski, P., Staskawicz, B., and Dinesh-Kumar, S. P. 1997. Signaling in plant-microbe interactions. Science 276:728-733. 
Berry, J. O., Nikolau, B. J., Carr, J. P., and Klessig, D. F. 1985. Transcriptional and post-transcriptional regulation of ribulose 1,5bisphosphate carboxylase gene expression in light- and dark-grown amaranth cotyledons. Mol. Cell. Biol. 5:2238-2246.

Bowles, D. J. 1990. Defense-related proteins in higher plants. Annu. Rev. Biochem. 59:873-907.

Bradford, M. M. 1976. A rapid and sensitive method for the quantification of microgram quantities of protein utilizing the principle of protein dye-binding. Anal. Biochem. 72:248-254.

Brunt, A., Crabtree, K., Dallwitz, M., Gibbs, A., and Watson, L. 1997. Viruses of plants. Descriptions and lists from the VIDE database. CAB Int., Wallingford, UK.

Carr, J. P., Gal-On, A., Palukaitis, P., and Zaitlin, M. 1994. Replicasemediated resistance to cucumber mosaic virus in transgenic plants involves suppression of both virus replication in the inoculated leaves and long-distance movement. Virology 199:439-447.

Carrington, J. C., Kasschau, K. D., Mahajan, S. K., and Schaad, M. C. 1996. Cell-to-cell and long-distance transport of viruses in plants. Plant Cell 8:1669-1681.

Chivasa, S., Murphy, A. M., Naylor, M., Carr, J. P. 1997. Salicylic acid interferes with tobacco mosaic virus replication via a novel salicylhydroxamic acid-sensitive mechanism. Plant Cell 9:547-557.

Day, D. A., Whelan, J., Millar, A. H., Siedow, J. N., and Wiskich, J. T. 1995. Regulation of the alternative oxidase in plants and fungi. Aust. J. Plant Physiol. 22:497-509.

Ding, X., Shintaku, M. H., Carter, S. A., and Nelson, R. S. 1996. Invasion of minor veins of tobacco leaves inoculated with tobacco mosaic virus mutants defective in phloem-dependent movement. Proc. Natl. Acad. Sci. USA 93:11155-11160.

Durner, J., Shah, J., and Klessig, D. F. 1997. Salicylic acid and disease resistance in plants. Trends Plant Sci. 2:266-274.

Friedrich, L., Lawton, K., Ruess, W., Masner, P., Specker, N., Gut-Rella, M., Meier, B., Dincher, S., Staub, T., Uknes, S., Métraux, J.-P., Kessmann, H., and Ryals, J. 1996. A benzothiadiazole derivative induces systemic acquired resistance in tobacco. Plant J. 10:61-70.

Gal-On, A., Kaplan, I. B., Roossinck, M., and Palukaitis, P. 1994. The kinetics of infection of zucchini squash by cucumber mosaic virus indicate a function of RNA 1 in virus movement. Virology 205:280-289.

Gilbertson, R. L., and Lucas, W. J. 1996. How do viruses traffic on the 'vascular highway'? Trends Plant Sci. 1:260-268.

Hayes, R. J., and Buck, K. W. 1990. Complete replication of a eucaryotic virus RNA in vitro by a purified RNA-dependent RNA polymerase. Cell 63:363-368.

Hayes, R. J., and Buck, K. W. 1993. Analysis of replication complexes of positive strand RNA viruses. Pages 1-34 in: Molecular Virology: A Practical Approach. A. J. Davidson and R. M. Elliott, eds. IRL Press, Oxford.

Hooft van Huijsduijnen, R. A. M., Alblas, S. W., De Rijk, R. H., and Bol, J. F. 1986. Induction by salicylic acid of pathogenesis-related proteins and resistance to alfalfa mosaic virus infection in various plant species. J. Gen. Virol. 67:2143-2153.

Köhm, B. A., Goulden, M. G., Gilbert, J. E., Kavanaugh, T. A., and Baulcombe, D. C. 1993. A potato virus X resistance gene mediates an induced, non-specific resistance in protoplasts. Plant Cell 5:913-920.

Laties, G. G. 1982. The cyanide-resistant, alternative path in plant mitochondria. Annu. Rev. Plant Physiol. 33:519-555.

Leisner, S., and Howell, S. H. 1993. Long-distance movement of viruses in plants. Trends Microbiol. 1:314-317.

Leisner, S. M., and Turgeon, R. 1993. Movement of virus and photoassimilate in the phloem: A comparative analysis. BioEssays 15:741-748.

Leisner, S. M., Turgeon, R., and Howell, S. H. 1992. Long distance movement of cauliflower mosaic virus in infected turnip plants. Mol. Plant-Microbe Interact. 5:41-47.

Lucas, W. J., Olesinski, A., Hull, R. J., Haudenshield, J. S., Deom, C. M., Beachy, R. N., and Wolf, S. 1993. Influence of the tobacco mosaic virus $30-\mathrm{kDa}$ movement protein on carbon metabolism and photosynthate partitioning in transgenic tobacco plants. Planta 190:88-96.

Malamy, J., Carr, J. P., Klessig, D. F., and Raskin, I. 1990. Salicylic acid: a likely endogenous signal in the resistance of tobacco to viral infection. Science 250:1002-1004.

Maule, A. J. 1991. Virus movement in infected plants. Crit. Rev. Plant Sci. 9:457-473

McIntosh, L. 1994. Molecular biology of the alternative oxidase. Plant Physiol. 105:781-786.
Métraux, J.-P., Signer, H., Ryals, J., Ward, E., Wyss-Benz, M., Gaudin, J., Raschdorf, K., Schmid, E., Blum, W., and Inverardi, B. 1990. Increase in salicylic acid at the onset of systemic acquired resistance in cucumber. Science 250:1004-1006.

Mur, L. A. J., Bi, Y.-M., Darby, R. M., Firek, S., and Draper, J. 1997. Compromising early salicylic acid accumulation delays the hypersensitive response and increases viral dispersal during lesion establishment in TMV-infected tobacco. Plant J. 12:1113-1126.

Padgett, H. S., Watanabe, Y., and Beachy, R. N. 1997. Identification of the TMV replicase sequence that activates the $N$ gene-mediated hypersensitive response. Mol. Plant-Microbe Interact. 10:709-715.

Palukaitis, P., Roossinck, M. J., Dietzgen, R. G., and Francki, R. I. B 1992. Cucumber mosaic virus. Adv. Virus Res. 41:281-348.

Pennazio, S., Roggero, P., and Gentile, I. A. 1985. Effects of salicylate on virus-infected tobacco plants. Phytopathol. Z. 114:203-213.

Raskin, I. 1992. Role of salicylic acid in plants. Annu. Rev. Plant Physiol. Plant Mol. Biol. 43:439-463.

Reuber, T. L., and Ausubel, F. M. 1996. Isolation of Arabidopsis genes that differentiate between resistance responses mediated by the RPS2 and RPM1 disease resistance genes. Plant Cell 8:241-249.

Ritter, C., and Dangl, J. L. 1996. Interference between two specific pathogen recognition events mediated by distinct plant disease resistance genes. Plant Cell 8:251-257.

Roberts, A. G., Santa Cruz, S., Roberts, I. A., Prior, D. A. M., Turgeon, R., and Oparka, K. J. 1997. Phloem unloading in sink leaves of Nicotiana benthamiana: Comparison of a fluorescent solute with a fluorescent virus. Plant Cell 9:1381-1396.

Ross, A. F. 1961a. Localized acquired resistance to plant virus infection in hypersensitive hosts. Virology 14:329-339.

Ross, A. F. 1961b. Systemic acquired resistance induced by localized virus infections in plants. Virology 14:340-358.

Ryals, J. A., Neuenschwander, U. H., Willits, M. G., Molina, A., Steiner, H.-Y., and Hunt, M. D. 1996. Systemic acquired resistance. Plant Cell 8:1809-1819.

Séron, K., and Haenni, A.-L. 1996. Vascular movement of plant viruses. Mol. Plant-Microbe Interact. 9:435-442.

Staskawicz, B. J., Ausubel, F. M., Baker, B. J., Ellis, J. G., and Jones, J. D. G. 1995. Molecular genetics of plant disease resistance. Science 268:661-667.

Técsi, L. I., Maule, A. J., Smith, A. M., and Leegood, R. C. 1994. Complex, localized changes in $\mathrm{CO}_{2}$ assimilation and starch content associated with the susceptible interaction between cucumber mosaic virus and a cucurbit host. Plant J. 5:837-847.

Thompson, J. R., and García-Arenal, F. 1998. The bundle sheath-phloem interface of Cucumis sativus is a boundary to systemic infection by tomato aspermy virus. Mol. Plant-Microbe Interact. 11:109-114.

Turgeon, R. 1989. The sink-source transition in leaves. Annu. Rev. Plant Physiol. Plant Mol. Biol. 40:119-138.

Turgeon, R., and Webb, J. A. 1973. Leaf development and phloem transport in Cucurbita pepo: Transition from import to export. Planta 113:179-191.

Vidal, S., Eriksson, A. R. B., Montesano, M., Denecke, J., and Palva, E. T. 1998. Cell wall-degrading enzymes from Erwinia carotovora cooperate in the salicylic acid-independent induction of a plant defense response. Mol. Plant-Microbe Interact. 11:23-32.

Wang, J.-L., Turgeon, R., Carr, J. P., and Berry, J. O. 1993. Carbon sinkto-source transition is coordinated with establishment of cell-specific gene expression in a C4 plant. Plant Cell 5:289-296.

White, R. F., Antoniw, J. F., Carr, J. P., and Woods, R. F. 1983. The effects of aspirin and polyacrylic acid on the multiplication and spread of TMV in different cultivars of tobacco with and without the $\mathrm{N}$-gene. Phytopathol. Z. 107:224-232.

Whitham, S., Dinesh-Kumar, S. P., Choi, D., Hehl, R., Corr, C., and Baker, B. 1994. The product of the tobacco mosaic virus resistance gene N: Similarity to Toll and the interleukin-1 receptor. Cell 78: 1101-1115.

Wintermantel, W. M., Banerjee, N., Oliver, J. C., Paolillo, D. J., and Zaitlin, M. 1997. Cucumber mosaic virus is restricted from entering minor veins in transgenic tobacco exhibiting replicase-mediated resistance. Virology 231:248-257.

Xu, Y., Chang, P.-F. L., Liu, D., Narasimhan, M. L., Raghothama, K. G., Hasegawa, P. M., and Bressan, R. A. 1994. Plant defense genes are synergistically induced by ethylene and methyl jasmonate. Plant Cell 6:1077-1085 